Jacek Karwowski*

\title{
CENTRAL COUNTERPARTIES FROM THE ISLAMIC FINANCE PERSPECTIVE
}

\section{Introduction}

Trading in the OTC securities or derivatives markets is bilateral and it takes place either between dealers or between dealers and their clients. However, a very significant volume of contracts is re-traded with central clearing counterparties (CCPs) via a process called novation or similar, wherein the CCP becomes a buyer to one counterparty and seller to the other. Especially the OTC derivatives market created difficulties for regulators, but also for the banks involved. According to the decision of G20 leaders from 2009, "All standardised OTC derivative contracts should be traded on exchanges or electronic trading platforms, where appropriate, and cleared through central counterparties by end-2012 at the latest"'. All OTC derivatives contracts in the EU (with exemption of some exotic contracts) should be traded through a CCP rather than bilaterally according to the European Markets Infrastructure Regulation (EMIR), prepared by the European Securities and Markets Authority ${ }^{2}$. Similar solution was applied in the US (Dodd-Frank Act). This goal has not been reached, but progress is on its way.

This paper has a double purpose. First, to apply principles worked out by the Bank for International Settlement (BIS) and the International Organization of Securities Commissions (IOSCO) $)^{3}$ to the CCPs in the countries where Islamic finance plays

\footnotetext{
* Uniwersytet Ekonomiczny we Wrocławiu, Wydział Nauk Ekonomicznych.

1 Financial Stability Board, OTC Derivatives Market Reforms. Fifth Progress Report on Implementation, 15 April 2013, Foreword.

2 Regulation (EU) No 648/2012 of the European Parliament and of the Council of 4 July 2012 on OTC derivatives, central counterparties and trade repositories.

3 Principles for financial market infrastructures, Bank for International Settlements and International Organization of Securities Commissions, April 2012. The standards in this report harmonize and, where appropriate, strengthen the international standards for payment systems that are systemically important, central securities depositories, securities settlement systems, and central counterparties.
} 
a major role, and second, to show how the specific rules of Islamic finance influence the functioning of CCPs.

\section{The financial architecture}

Financial market infrastructure is defined as "a multilateral system among participating institutions, including the operator of the system, used for the purposes of clearing, settling, or recording payments, securities, derivatives, or other financial transactions"4. It may obviously strengthen the markets they serve and play a critical role in achieving financial stability.

A payment system (PS) is a set of instruments, procedures, and rules for the transfer of funds between participants. The system encompasses the entity operating the arrangement and the participants. It may take a form of real-time gross settlement systems, deferred net settlement systems or a hybrid, with their own characteristics important from the payment finality perspective.

A central securities depository (CSD) provides securities accounts, central safekeeping services, and asset services, and plays an important role in helping to ensure that securities are not accidentally or fraudulently created or destroyed or their details changed. Quite often a CSD also operates a securities settlement system.

A securities settlement system (SSS) allows the securities to be transferred and settled by book entry according to predefined rules. This entity is responsible (in its minimum form) for the process of clearing and settling a securities trade, which includes three key steps: the confirmation of the settlement obligations; clearance (the calculation of the obligations of the counterparties resulting from the confirmation process); and settlement (the final transfer of securities in exchange for final transfer of funds in order to settle the obligations).

A central counterparty (CCP), being the main topic of this paper, "interposes itself between counterparties to contracts traded in the financial markets, becoming the buyer to every seller and the seller to every buyer and thereby ensuring the performance of open contracts". It is done through novation ${ }^{5}$, open offer ${ }^{6}$, or another legally binding arrangement. A CCP, through clearing, has the potential to reduce its

4 All definitions of the terms in bold (below) are based on Principles for financial market infrastructures, op. cit., pp. 5-10.

5 In the case of novation, an existing contract is terminated and replaced by two contracts with the CCP.

6 Open offer means that a contract is concluded with the CCP immediately after the matching of trading details. 
participants' risks significantly by multilaterally netting trades and imposing more effective risk controls on all participants. A CCP's typical risk controls include requiring participants to provide a margin to cover current and potential future exposures ${ }^{7}$, collecting and paying mark-to-market losses and gains frequently to reduce current exposure, and requiring participants to share residual risk in the event that one or more participant defaults. In case of centrally cleared OTC derivatives some standardisation is required for contracts handled by CCP, but they do not need to have all the features that would allow exchange trading (e.g. high liquidity).

A trade repository (TR) is an entity that maintains a centralised electronic database of transaction data. By centralising the collection, storage, and dissemination of data, a well-designed TR can serve an important role in enhancing the transparency of transaction information to relevant authorities and the public, promoting financial stability, and supporting the detection and prevention of market failure.

As we can see, there are several interconnected organisations on the financial markets, which perform complementary functions, aiming to secure after-trade activities and thus securing the whole trading process. All of them seem necessary, but in this paper primary interest will be given to the central counterparties, as they not only reduce credit risk associated with individual transactions but also diminish systemic risk. Other reason for importance of CCPs is their potential implementation on the OTC derivatives markets.

The global market structure of the provision of clearing services is monopolistic within a number of risk or product classes. Global clearing of OTC interest rate products occurs almost exclusively through the SwapClear subsidiary of the U.K. CCP LCH.Clearnet, and global clearing of OTC CDS is dominated by the CCP InterContinental Exchange's (ICE) U.S. and U.K. subsidiaries, ICE Clear Credit and ICE Clear Europe ${ }^{8}$.

\section{Central counterparties and risk}

Several risk categories are associated with the post-sale procedures on the financial markets.

\footnotetext{
7 Margin is perceived as positive because of the ability to cover losses, but in fact constitutes a burden (own capital which has to be paid in) for a party entering the trade.

8 L. Lin, J. Surti, Capital Requirements for Over-the-Counter Derivatives Central Counterparties, IMF Working Paper WP/13/3, January 2013, p. 5.
} 
Credit risk is probably the most evident kind of risk; it refers to the counterparty's ability to meet its financial obligations. This is the obvious area where CCP is needed. The idea behind it is shown in Figure 1, where E indicates the payment due from other parties, before and after the central clearing.

Figure 1. Mechanics of credit risk reduction by transferring bilateral derivatives contracts to CCP
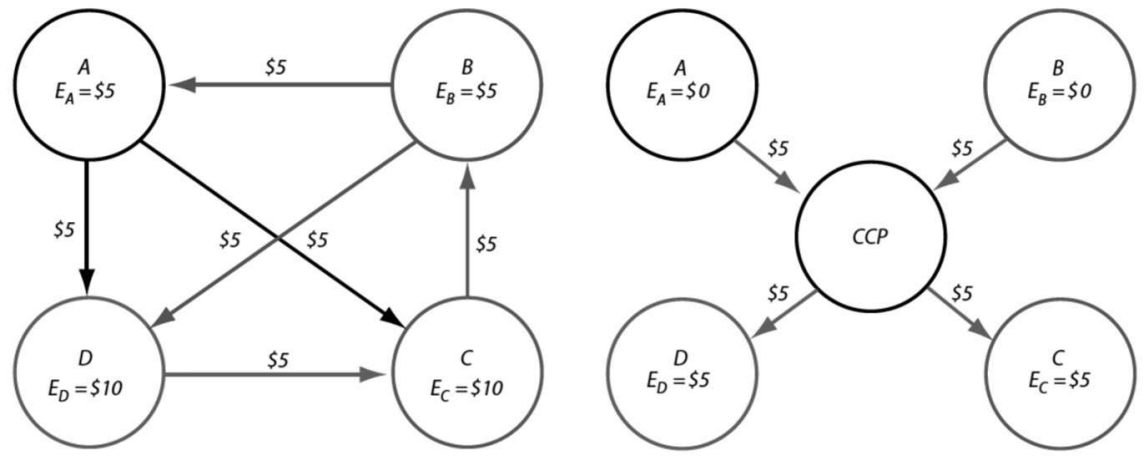

Source: Meeting New Challenges to Stability and Building a Safer System, Global Financial Stability Report, International Monetary Fund, Washington 2010, April, p. 98.

A benefit of central clearing is clear at a glance: first, it is the multilateral netting of several transactions between market participants, which simplifies outstanding exposures compared with a plenty of bilateral settlements. Netting exposure across members allows smaller net exposure. But the other benefit, i.e. the reduction of the counterparty risk, is more important: the CCPs effectively guarantee the obligations under agreement between the two counterparties, provided both use the settlement mechanisms offered by the CCP. If one counterparty fails, the other (at least in the short run) is protected by the default management procedures and resources of the CCP. In taking on the obligations of each side to a transaction, a CCP has equal and opposite contracts. But if one member defaults, the CCP needs resources to draw on to continue meeting its obligations to surviving members.

A CCP will typically have five lines of defence before it runs out of resources to handle a clearing member default. The first line is the initial and variation margins posted to the CCP. Second one is the defaulting members' default fund contribution. Another buffer is the CCP contributed capital and the last one: contributions of non-defaulting clearing members' to the default fund ${ }^{9}$.

9 http://cooconnect.com/news/risk-waterfalls-webinar-\%E2\%80\%93-when-do-i-start-lose-my-moneysummary-key-points 
The involvement of CCPs does not mean the risks disappear. They are passed to CCP where they may be, hopefully, better managed. If a market participant becomes insolvent, its losses will still be borne by some or all of its creditors ${ }^{10}$. In other words, then we face a redistribution of the counterparty risk: replacing a partner's exposure is replaced by the credit risk on the central counterparty. It means however, that the CCPs themselves become crucial nodes in the financial network. "The systemic importance of CCPs is expected to increase further as the central clearing of standardised OTC derivatives becomes mandatory. This makes it essential for CCPs to manage properly the risks they face" 11 .

Liquidity risk is the risk that a counterparty will have insufficient funds to meet its financial obligations when expected, but the difficulties are preliminary. A typical case is that a seller of an asset will not receive payment when due, and the seller may have to borrow money or sell own assets to complete other payments (or the buyer will not receive an asset). This kind of risk cannot be easily solved by a CCP.

The parties involved in after-trade activities face also the risk of loss on their own assets and the assets they hold on behalf of other entities, e.g. collateral, which is a kind of investment risk.

Legal risk is the risk of application of an act or other regulation, resulting in a loss. It cannot be fully prevented, just like well-known operational risk. The concentration of operational risk in a central counterparty is considerably greater than that in any individual participant in a decentralised market.

The most important, however, from the perspective of stability of the whole financial system, is the systemic risk, i.e. the risk of collapse of an entire market (e.g. a specific derivatives market) or even of the whole financial system. It constitutes a threat to the stability of the financial system or its part, caused by low-probability events or conditions in financial intermediaries, which have adverse effects on many interlinked entities and severely harm the functioning of a system or a market, through cascading failures.

Under some circumstances, CCPs' actions may have 'procyclical' effects. For example, CCPs adjust initial margin demands in response to changes in market conditions, which is correct. But these margin changes will have a destabilising impact on the CCPs' members, forcing them to liquidate their positions or obtain extra liquidity in difficult times.

\footnotetext{
${ }^{10}$ Hills B., Rule D., Parkinson S., Young Ch., Central counterparty clearing houses and financial stability, Financial Stability Review, June 1999, p. 126.

${ }_{11}$ A. Rehlon, D. Nixon, Central counterparties: what are they, why do they matter and how does the Bank supervise them? Quarterly Bulletin 2013 Q2, Bank of England, pp. 2-4.
} 
But as a result, new or concentrated, risk arises: a CCP failing. "The most likely trigger for a CCP failure would be if one or many large clearing members defaulted"12.

A large CCP that fails could act as a trigger of contagion. The emergence of 'big' CCPs might however pose a threat for the system stability, like banks that are 'too big to fail'.

\section{Central counterparties in Islamic finance: restrictions, limitations and proposals}

Before we formulate some remarks concerning relations between the CCPs and Islamic finance, we will look closer at CCPs in Malaysia, which is one of the major Islamic financial centres and the only Islamic country for which assessment of observance of the CPSS-IOSCO principles for financial market infrastructures was done ${ }^{13}$.

Securities and derivatives clearing and settlement infrastructure is managed by an integrated exchange holding company: Bursa Malaysia Berhad (BM). BM's 100\% subsidiary, Bursa Malaysia Securities (BMS), is the stock exchange, where all equities, warrants, ETFs, REITs, commercial papers and sukuk are traded ${ }^{14}$. Bursa Malaysia Derivatives Berhad (BMD), the sole derivatives exchange in Malaysia, is in $75 \%$ owned by BM. Chicago Mercantile Exchange (CME) holds the remaining 25\% stake. BMD provides, operates and maintains a futures and options exchange. Bursa Malaysia Derivatives (BMD) offers three categories of derivatives: Commodity Derivatives, Equity Derivatives and Financial Derivatives. BMD's derivatives products are available on the CME Globex electronic trading platform for better accessibility, visibility, and distribution globally. BMD operates the most liquid and successful crude palm oil futures (FCPO) contract in the world ${ }^{15}$.

Bursa Malaysia Securities Clearing Berhad (BMSC) and Bursa Malaysia Derivatives Clearing Berhad (BMDC), are wholly owned subsidiaries of BM and

$12 \mathrm{http}$ //ids.thomasmurray.com/myInvestorCircle/regulators-unsure-how-cope-central-counterparty-default. The examples of CCP failures in the past are: Caisse de Liquidation des Affaires en Marchandises in 1974 (when traders were unable to meet margin calls), the Malaysian Kuala Lumpur Commodity Clearing House was closed down in 1983 as a result of unmet margin calls after a crash in palm oil futures prices on the Kuala Lumpur Commodity Exchange. The Hong Kong Futures Exchange also had to be rescued by the government in 1987.

13 Assessment of Observance of the CPSS-IOSCO Principles for Financial Market Infrastructures. Detailed Assessment of Observance. IMF, The World Bank, February 2013, p. 1.

14 http://www.opf.com.my/futures-products/futures-exchanges/bursa-malaysia-derivatives-bmd

15 http://www.opf.com.my/futures-products/futures-exchanges/bursa-malaysia-derivatives-bmd 
$\mathrm{BMD}$, and approved central counterparties for the Malaysian securities exchange and derivatives market, respectively. All the matched exchange trades are sent to the $\mathrm{BMSC} / \mathrm{BMDC}$ for the clearing and settlement ${ }^{16}$.

The assessment of observance of the CPSS-IOSCO principles ${ }^{17}$ shows that most of them are observed, and only four are broadly observed. There is a good reason to concentrate on the issues of concern first $(\mathrm{P} 1,7,9,13,14,17,23)$. Then we analyse the applicability of other CCP-related principles for Islamic finance in general, if any clarification is needed.

Let's start with the legal issues. The report from the assessment states that both netting and novation are not explicitly addressed in two major acts governing derivatives trades: Capital Market Services Act (2007) and Securities Commission Act (1993) (P1). This is not very dangerous, because these actions are defined and applied elsewhere. Similarly, non-critical are the recommendations concerning P23 Disclosure of rules, key procedures, and market data; in addition they lower gharar. Potentially more important is P13, which assumes effective and clearly defined rules and procedures to manage a participant default.

Rather crucial are the issues related to money settlements (P9), but not necessarily for Islamic institutions; BMDC should conduct its money settlements in central bank money instead of commercial bank money. This recommendation is symptomatic; after last crisis experience no commercial bank is safe enough, only central bank money matters. It corresponds to P7: the BMDC should create specific stress tests for simulating liquidity risk (unavailability of one or more banks which they maintain their liquid assets), in addition to credit risk stress tests. This recommendation is especially difficult for Islamic financial institutions, because they lack sufficient liquid instruments, with exception of cash. Their competitive position is therefore impaired.

The International Islamic Liquidity Management Corporation (IILM) was established 2010 in Kuala Lumpur, Malaysia, by several central banks and the Islamic Development Bank from Saudi Arabia. The IILM seeks to facilitate cross-border liquidity management among institutions offering Islamic financial services by making available a variety of Sharia-compliant instruments, on commercial terms, to suit the varying liquidity needs of these institutions. The IILM seeks to foster regional

${ }^{16}$ Assessment of Observance of the CPSS-IOSCO Principles for Financial Market Infrastructures. Detailed Assessment of Observance. IMF, The World Bank, February 2013, p. 9.

17 The standards in this report harmonise and, where appropriate, strengthen the international standards for payment systems that are systemically important, central securities depositories, securities settlement systems, and central counterparties. The revised standards also incorporate additional guidance for OTC derivatives CCPs and trade repositories. 
and international co-operation to build a robust liquidity management infrastructure at national, regional and international levels ${ }^{18}$.

IILM issues wakala sukuk ${ }^{19}$ in the name of the company itself (as SPV), but the assets that underpin the issuance are held by selected central banks which act as custodians. This feature, on one hand, raises the confidence of the buyers of the sukuk and allows high rating, which justifies the usage of these assets for banks' liquidity management. The range of assets that backup the sukuk is broad: istisna, equities issued by companies complying with Sharia guidelines, murabaha, other sukuk or even selected derivative products, provided they meet Sharia guidelines. Transactions are centrally recorded and registered, also on the secondary market, and IILM performs the function of CCP. On the other hand, the engagement of many central banks diminishes the benefits of CCP, because they may apply different (own) law than the law of Malaysia. In addition, the information concerning sukuk assets is possibly not standardised.

Another crucial topic is segregation and portability (P14): BMDC (CCP) should review rules and procedures that enable the segregation and portability of positions of participant's customers and the collateral provided with respect to those positions. Which collaterals Islamic financial institutions should post is not easy to identify, but the standards outlined by the Islamic Financial Services Board (IFSB ${ }^{20}$ in Malaysia may be helpful. A kind of restriction is the limited disposability of selected instruments which cannot be sold on the secondary market (see comment on P5 below). Other principles had managerial (P13) or technical (P17) character.

Now let's turn to other CCP-related CPSS-IOSCO principles and comment on them, if any clarification in relation to Islamic finance is needed. Table 1 suggests whether the principle is neutral $(\mathrm{N})$, whether Islamic finance is/should be more restrictive (R) than traditional requirements, or it is just not applicable (N/A).

Table 1. Application of CPSS-IOSCO principles for Islamic financial institutions

\begin{tabular}{|c|c|c|c|c|c|c|c|c|c|c|c|}
\hline $\mathbf{1}$ & $\mathbf{2}$ & $\mathbf{3}$ & $\mathbf{4}$ & $\mathbf{5}$ & $\mathbf{6}$ & $\mathbf{7}$ & $\mathbf{8}$ & $\mathbf{9}$ & $\mathbf{1 0}$ & $\mathbf{1 1}$ & $\mathbf{1 2}$ \\
\hline $\mathrm{N}$ & $\mathrm{R}$ & $\mathrm{R}$ & $\mathrm{R}$ & $\mathrm{R}$ & $\mathrm{R}$ & $\mathrm{R}$ & $\mathrm{N}$ & $\mathrm{N}$ & $\mathrm{N}$ & $\mathrm{N} / \mathrm{A}$ & $\mathrm{R}$ \\
\hline $\mathbf{1 3}$ & $\mathbf{1 4}$ & $\mathbf{1 5}$ & $\mathbf{1 6}$ & $\mathbf{1 7}$ & $\mathbf{1 8}$ & $\mathbf{1 9}$ & $\mathbf{2 0}$ & $\mathbf{2 1}$ & $\mathbf{2 2}$ & $\mathbf{2 3}$ & $\mathbf{2 4}$ \\
\hline $\mathrm{N}$ & $\mathrm{R}$ & $\mathrm{N}$ & $\mathrm{R}$ & $\mathrm{N}$ & $\mathrm{N}$ & $\mathrm{N} / \mathrm{A}$ & $\mathrm{N}$ & $\mathrm{N}$ & $\mathrm{N}$ & $\mathrm{N}$ & $\mathrm{N} / \mathrm{A}$ \\
\hline
\end{tabular}

Source: Own considerations.

\footnotetext{
18 www.iilm.com

${ }^{19}$ For a detailed description of wakala sukuk see: http://www.islamicbanker.com/education/sukuk -al-wakala

${ }^{20} \mathrm{http}: / /$ www.ifsb.org/published.php
} 
P2 (governance) surely needs adjustments in respect to Sharia rules. P3 (framework for the comprehensive management of risks), P4 (credit risk): in 2005 IFSB already published the guidelines for risk management in Islamic financial institutions. ${ }^{21}$ This document defines all kinds of risks faced by (Islamic) financial institutions and provides operational considerations for them. Unfortunately, the recommendations have a rather general character or are obvious. They refer to selected Islamic instruments, but not in a systematic way; instead, some instruments are used as examples. P5 (collateral): the restrictions are related to a set of allowed securities. A list of the 'Islamic' securities is shorter, and not all of them may be traded on secondary markets. The risk associated with them may also be higher, and it will be demonstrated in higher haircuts. P6 (margin) relates to payments of margin (initial, maintenance), e.g. to the futures exchange. Islamic finance has a problem with it because it supports gambling (a margin covers losses resulting from price changes). There are attempts to implement bai al-urboun ${ }^{22}$ for options. However, it is not the posting of margin that is a major problem for Islamic institutions, but the underlying instruments, which are not Sharia-compliant. P12 (exchange-of-value settlement system) concerns settlements using delivery versus payment, delivery versus delivery, and payment versus payment. In general, CCP should ensure that delivery occurs if and only if the corresponding payment occurs. It shouldn't be problematic for Islamic finance, because it presumes the equality of parties (and not conditionality of contracts). P16 (custody and investment risks) is about safeguarding the assets belonging to CCP and its participants. From the Islamic institution's point of view it matters how CCP will hold its assets (e.g. investments involving riba).

Now, some conclusions about the relationships between CCPs and Islamic finance:

1. The standardisation of Islamic contracts is a prerequisite for extensive usage of CCPs. The clearing of small number of very different instruments cannot be done, at least not effectively. Two international organisations, Islamic Financial Services Board (IFSB) ${ }^{23}$ in Malaysia and Accounting and Auditing Organisation for Islamic Financial Institutions (AAOIFI) ${ }^{24}$ in Bahrain have generated a series

${ }^{21}$ Guiding principles of risk management for institutions (other than insurance institutions) offering only Islamic financial services, IFSB, Kuala Lumpur 2005.

22 A type of sale in which the seller receives a nominal advance on account from the prospect buyer. This advance amount gives the buyer the right to decide whether to proceed with the contract or rescind it. If the transaction is struck, the advance will be considered part of the price, and the buyer will have to pay the remaining amount and take delivery of the underlying. And if the transaction is cancelled, the seller will keep the urboun (http://www.investment-and-finance.net/islamic-finance/b/bai-al-urboun.html).

${ }^{23}$ www.ifsb.org

${ }^{24}$ www.aaoifi.org 
of standards, but they are surprisingly rarely applied ${ }^{25}$. Without standardisation it is for example not possible to easily calculate the obligations of counterparties deriving from different transactions for netting purposes.

2. Riba-related limitations; the real-time gross settlement or another PS is needed both in traditional and Islamic finance. However, it usually includes intra-day credit or central bank credit facility. This may also be needed in case of serious market disruption when the ultimate source of liquidity is provided. The PS should allow Islamic banks not to pay interest upon usage and allow only Islamic securities to be pledged as collateral at the central bank.

3. Some transactions, especially derivatives, are not allowed in Islamic finance because of gharar, excessive uncertainty, or maysir, gambling. In fact, all derivatives, especially financial ones, may be regarded as non-conforming with Sharia, at least for three reasons. First, an outcome of the transaction (profit or loss) depends on good or bad luck. Second, the derivatives are often used for excessive speculation. Third, the payments connected with derivatives often are based on $r i b a^{26}$. Accordingly, the implementation of CCPs is not important because the transactions are forbidden or very limited. Even if some kinds of derivatives are allowed in Islamic finance, serious limitations have to be observed and the number of parallel transactions will be low (see next point).

4. The advantages of CCP are observed if the number of participants is high and relations between them are complex. To illustrate this, consider only 3 counterparties in Figure 1 (A, C and D). Without B the introduction of CCP may reduce the counterparty risk but not the net obligations of the parties involved (still 10 in total). This remark has nothing to do with the Islamic transactions as such, but they are still relatively small and do not engage large number of counterparties ${ }^{27}$.

5. The main characteristic feature of Islamic financial transactions is the extensive usage of several transactions in goods. One simple (from the conventional point of view) financial transaction consists of several sales of goods in the Islamic world. For CCP it has far-reaching consequences - it should organise and allow delivery of goods.

\footnotetext{
${ }^{25}$ P. Koster, Implications of International Regulatory Change for Islamic Finance, IFSB $3^{\text {rd }}$ public lecture on financial policy and stability, Kuala Lumpur 2009, p. 27.

${ }^{26}$ I. Iqbal, S. Kunhibava, A.W. Dusuki, Application of Options in Islamic Finance, ISRA Research Paper No. 46/2012, p. 10.

${ }^{27}$ Islamic finance is still only around $1 \%$ of conventional finance (P. Koster, Implications of International Regulatory Change for Islamic Finance, op.cit., p. 22).
} 
6. Some goods, like gold and silver, for religious reasons are not allowed in Islam for trading other than spot trading (because they are regarded as money).

7. From the Islamic finance perspective, the securities clearing may be problematic as far the securities are 'non-Islamic' (e.g. debt, stocks of companies producing pork or weapons). However, one may assume Islamic investors will not buy (and accordingly sell) any such securities. Other, conventional investors will use the services of CCP (like BMSC) without any negative consequences for the Islamic ones.

8. The introduction of CCPs to OTC derivatives trades, widely encouraged, might be problematic for Islamic banks. Even if the transaction is allowed according to Sharia, some of Islamic transaction elements might not be accepted by a traditional CCP. In addition, margin requirements entail charging of riba, which is forbidden for Islamic financial institutions. The Bahrain-based International Islamic Financial Market (IIFM) specialises in standardisation of Islamic financial products, documentation, and related processes at the global level. IIFM considers Sharia compliant CCP, but so far (March 2015) no concept was presented ${ }^{28}$.

\section{Conclusions}

Central counterparties play a major role in the current financial infrastructure, especially in the aftermath of the last crisis. They interpose themselves between counterparties to contracts traded in the financial markets, becoming the buyer to every seller and the seller to every buyer, and thereby ensuring the performance of open contracts. A CCP, through clearing, has the potential to significantly reduce its participants' risks by multilaterally netting trades and imposing more-effective risk controls on all participants. The aim of this paper was to analyse how the principles concerning CCPs worked out by the BIS and IOSCO apply to Islamic finance. We conclude that all general principles apply to Islamic finance. In a few cases the specific rules of Islamic finance influence the functioning of CCPs, posing additional restrictions on general principles. We pointed out the limitations of current Islamic instruments, which make it difficult to exploit all the advantages of CCPs.

${ }^{28} \mathrm{http}$ ///arynews.tv/en/islamic-finance-body-iifm-develop-trade-corporate-finance-contracts/ 


\section{References}

Assessment of Observance of the CPSS-IOSCO Principles for Financial Market Infrastructures. Detailed Assessment of Observance. IMF, The World Bank, February 2013.

Guiding principles of risk management for institutions (other than insurance institutions) offering only Islamic financial services, IFSB, Kuala Lumpur 2005.

Hills B., Rule D., Parkinson S., Young Ch., Central counterparty clearing houses and financial stability, "Financial Stability Review", June 1999.

Iqbal I., Kunhibava S., Dusuki A.W., Application of Options in Islamic Finance, ISRA Research Paper 2012, No. 46.

Koster P., Implications of International Regulatory Change for Islamic Finance, IFSB $3^{\text {rd }}$ public lecture on financial policy and stability, Kuala Lumpur 2009.

Lin L., Surti J., Capital Requirements for Over-the-Counter Derivatives Central Counterparties, IMF Working Paper WP/13/3, January 2013.

Meeting New Challenges to Stability and Building a Safer System, Global Financial Stability Report, International Monetary Fund, Washington 2010, April.

OTC Derivatives Market Reforms. Fifth Progress Report on Implementation. Financial Stability Board, 15 April 2013.

Principles for financial market infrastructures, Bank for International Settlements and International Organization of Securities Commissions, April 2012.

Regulation (EU) No 648/2012 of the European Parliament and of the Council of 4 July 2012 on OTC derivatives, central counterparties and trade repositories.

Rehlon A., Nixon D., Central counterparties: what are they, why do they matter and how does the Bank supervise them? Quarterly Bulletin 2013 Q2, Bank of England.

www.aaoifi.org

www.cooconnect.com

www.ids.thomasmurray.com

www.ifsb.org

www.iilm.com

www.investment-and-finance.net

www.islamicbanker.com

www.opf.com.my 


\section{Central Counterparties from the Islamic Finance's Perspective}

The paper focuses on central counterparties (CCPs) becoming the buyer to every seller and the seller to every buyer and thereby ensuring the performance of open contracts. The role of CCPs increased considerably after outbreak of the crisis in 2008 .

In 2012 BIS and IOSCO published the Principles for financial market (post-trade) infrastructures. The aim of the paper is to find out whether, and if yes - to what extent, the mentioned principles have to be modified when applied to CCP serving Islamic financial institutions. It seems that all principles are appropriate for Islamic finance, however some of them should be modified in order to be Shariacompliant. Moreover, in some cases the modification might also be difficult due to lack of standardized instruments.

Keywords: Islam finance, central counterparties

\section{Les contreparties centrales dans la perspective de la finance islamique}

Le document met l'accent sur les contreparties centrales devenant l'acheteur pour chaque vendeur et le vendeur pour chaque acheteur et assurant ainsi l'exécution des contrats ouverts. Le rôle des contreparties centrales a augmenté considérablement après le déclenchement de la crise en 2008. En 2012, la BRI et l'OICV ont publié les Principes pour les infrastructures de marchés financiers. Le but de l'article est d'analyser dans quelle mesure ces principes devraient être modifiés quand ils sont appliqués aux contreparties centrales en cas d'institutions financières islamiques. Il semble que tous les principes sont appropriés pour la finance islamique, mais certains d'entre eux devraient être modifiés afin d'être conformes à la charia. En outre, dans certains cas, la modification pourrait être difficile en raison du manque d'instruments standardisés.

Mots clés: la finance islamique, les contreparties centrales 


\section{Центральные контрагенты с точки зрения исламских финансов}

Статья посвящена роли центральных контрагентов (ЦК) на финансовом рынке, которые становятся покупателем для каждого продавца и продавцом для каждого покупателя, тем самым увеличивая безопасность торговли. Значение ЦК возросло после начала кризиса в 2008 г.

В 2012 г. БМР и МОКЦБ опубликовали руководящие принципы функционирования институтов, формирующих пост-трейдинговую инфраструктуру финансового рынка, в том числе ЦК. Цель статьи - рассмотреть должны ли эти правила быть изменены и в какой степени, если будут применяться к ЦК, работающим по принципам исламского финансирования. Кажется, что все принципы являются подходящими для исламских финансов, однако некоторые из них должны быть изменены для того, чтобы соответствовать шариату. Тем не менее, реализация некоторых модификаций может столкнуться с трудностями, связанными с отсутствием соответствующих стандартизированных финансовых инструментов, совместимых с шариатом.

Ключевые слова: исламские финансы, центральный контрагент (ЦК) 